\title{
Testosterone treatment in chronic heart failure. Review of literature and future perspectives
}

\author{
Roberta D'Assante1*, Lucrezia Piccioli2*, Pietro Valente², Francesca M. Stagnaro², \\ Alessandra Schiavo2, Anna Lombardi2, Veronica Panicara2, Michele Arcopinto33, \\ Giuseppe Vitale4, Filippo M. Sarullo4, Francesco Giallauria2, Alberto M. Marra1, \\ Andrea Salzano2,5 \\ 1 IRCCS SDN, Naples, Italy \\ 2 Department of Translational Medical Sciences, Federico II University, Naples, Italy \\ 3 Emergency Department, AORN “A. Cardarelli”, Naples, Italy \\ 4 Cardiovascular Rehabilitation Unit, Buccheri La Ferla Fatebenefratelli Hospital, Palermo, Italy \\ 5 Department of Cardiovascular Sciences and NIHR Leicester Biomedical Research Centre, \\ University of Leicester, Glenfield Hospital, Leicester, UK \\ * These authors equally contributed to the work
}

\begin{abstract}
Mounting evidence suggests that hormonal deficiencies (HD) have an important role in chronic heart failure (CHF). In particular, androgen depletion is common in men with CHF and is associated with increased morbidity and mortality. This review summarizes the current understanding of the complex relationship between CHF and testosterone, focusing on evidence derived from clinical trials that have investigated the role of testosterone in the treatment of CHF. A greater comprehension of this area will allow researchers and clinicians to plan future studies that improve current strategies to reduce mortality in this high-risk population. Online databases PubMed (Medline), Web of Science, and Scopus were searched for manuscripts published prior
\end{abstract}

Corresponding author: Dr. Andrea Salzano, Department of Translational Medical Sciences, Federico II University, Bldg. 18 1st floor, Via S. Pansini 5, 80131 Napoli, Italy - Department of Cardiovascular Sciences, University of Leicester, Clinical Sciences Wing, Glenfield Hospital, Leicester, LE3 9QP, UK.

E-mail: andrea.salzano@unina.it; andrea.salzano@leicester.ac.uk

Key words: Heart failure; cardiovascular disease; hormones; testosterone; anabolism; heart.

Acknowledgments: Dr. A. Salzano receives research grant support from Cardiopath.

Received for publication: 28 December 2017

Accepted for publication: 16 July 2018

(C) Copyright D'Assante et al., 2018

Tipografia PI-ME Editrice, Italy

Monaldi Archives for Chest Disease 2018; 88:976

doi: 10.4081/monaldi.2018.976

This article is distributed under the terms of the Creative Commons Attribution Noncommercial License (by-nc 4.0) which permits any noncommercial use, distribution, and reproduction in any medium, provided the original author(s) and source are credited. to June 2018 using key words "heart failure" AND "testosterone" OR "anabolism" OR "hormone" OR "replacement treatment". Manuscripts were collated, studied and carried forward for discussion where appropriate. In summary, findings from the literature demonstrate that testosterone treatment in $\mathrm{CHF}$ is a promising topic that requires further investigation.

\section{Introduction}

Since the previous view of chronic heart failure (CHF) as a syndrome merely based on disordered hemodynamic and fluid balance has switched into a view of the disease involving different molecular pathways in disarray, our understanding of CHF has improved dramatically $[1,2]$. CHF is now considered not only as a "cardiac disease" caused by alterations in the structure and function of the heart but as a "systemic disease" in which the interplay between myocardial factors, systemic inflammation, comorbidities, and neurohormonal activation plays a pivotal role [3]. With the aim of improving the assessment and treatment of patients with CHF, the current vision has progressed from a focus on the recovery and support of solely hemodynamic aspects of the patient's condition, to a more targeted view aimed at modifying the maladaptive molecular processes that contribute to progression of disease [4-6].

In this context, mounting evidence suggests that hormonal deficiencies (HD) have an important role in CHF [7-11]. In particular, androgen depletion is common in men with CHF and is associated with increased morbidity and mortality $[12,13]$. In this review, we summarize clinical data and potential applications of testosterone treatment in CHF.

\section{Testosterone and heart failure. Pathophysiological side}

The interaction between hormones and cardiac structure and function is an area that is well understood [14-18]. In this context, there are several studies sought to investigate the pathophysiological mechanisms underpinning this relationship.

The fact that androgen receptors (AR) are expressed in atrial and ventricular myocardial cells suggests that testosterone may act directly 
at the cellular level [19]. Testosterone and its active counterpart dihydrotestosterone exhibit biological effects by interacting with AR expressed on cell surfaces as well as in the cytosol. Androgens can mediate different response depending on the type of interaction with the receptor. AR expressed on the surface seem to be more responsible for the activation of ion channels and signaling pathways, while intracellular AR are involved in the modulation of androgen target genes that regulate myocardial and vascular cell activity [20]. In addition, polymorphisms of AR seem to play a role, in particular on metabolic profile [21]. Independently from its genomic effect, however, testosterone interacts with myocardial cells by regulating intracellular calcium $(\mathrm{Ca} 2+)$ homeostasis. Experiments performed on cardiomyocytes of rats showed that testosterone inhibits voltage-dependent $\mathrm{Ca} 2+$ channels, resulting in a rapid vaso-relaxation in both large arteries and smaller resistance vessels [20]. Moreover, it has been evaluated whether testosterone may have effects on the action potential duration (APD). Some observations suggest that low testosterone levels prolong APD, increase intracellular $\mathrm{Ca} 2+$ release and, consequently, the duration of contraction [22]. On the other hand, results obtained in gonadectomized female mice showed an increased neutrophil infiltration in the border zone of injured tissue after induction of myocardial infarction when compared with the same group supplemented with testosterone. These data suggest that testosterone is able to increase inflammation through neutrophil local infiltration after acute myocardial infarction. Moreover, this inflammatory status results also in a higher rupture rate during left ventricular remodeling and higher mortality rate secondary to cardiac rupture [23]. There are no clear data about the role and the importance of this inflammation.

Of note, evidence emerging form studies on testosterone deficiency suggest that testosterone is linked to the regulation of metabolic profile. In particular, endogenous testosterone levels improve lipid profile and reduce insulin resistance. Currently, there is no clear consensus on the association between endogenous testosterone levels and the effect of lipid profile, even though evidence suggests that testosterone inhibits the maturation of preadipocytes into mature adipocytes, reduces total fat mass and increases net lean mass [24,25]. In addition, recent evidence suggests that testosterone is a metabolic hormone that differentially regulates the expression of key targets of lipid and glucose metabolism in a tissue-specific manner to potentially reduce fat deposition in pathologically relevant locations such as the liver and arterial tree [26]. Moreover, testosterone improves fasting glucose levels and glucose tolerance. Indeed, it has been reported that men with low testosterone levels have double the risk of developing new onset type 2 diabetes and metabolic syndrome [27].

For this reason, it has been hypothesized that testosterone plays a pivotal role in the prevention of the metabolic syndrome [28].

\section{Testosterone and heart failure. Clinical side}

Several studies have investigated the role of testosterone in the treatment of CHF (Table 1).

The first of these was conducted in 12 stable male patients by Pugh et al. [29]. After administration of a single dose of testosterone (60 $\mathrm{mg}$ orally), the authors monitored central haemodynamic over $6 \mathrm{~h}$ using a pulmonary flotation catheter. Subjects received the second treatment on day 2 and haemodynamic monitoring was repeated. They observed an increase in cardiac output in the treated arm, mainly mediated by a reduction in peripheral resistance and left ventricular afterload. It is interesting to note that no side effects were reported and that results were more evident in patients with lower baseline levels of testosterone.
A few years later, the same group performed a double-blind, placebocontrolled study, enrolling 20 male CHF patients [30]. The treatment group (100 mg every 2 weeks for 12 weeks) showed a significant improvement in 6-minute walking distance and in the Minnesota living with heart failure questionnaire score. Following these promising results, they performed a larger randomized, double-blind, placebo-controlled trial in 76 CHF patients [31]. In the treated group (5 mg/day administered by an adhesive skin patch), authors demonstrated an improvement in clinical disease severity as demonstrated by the reduction of at least one NYHA class (30\% of patients vs $8 \%$ in treated and untreated, respectively). In addition, even if testosterone did not change left ventricular morphology or function, a significant improvement in shuttle walk distance was demonstrated. On the other hand, treatment had no significant effect on measurements of skeletal muscle bulk and strength, heart rate, blood pressure, nor weight. With regard to plasma concentrations of cytokines (e.g., TNF $\alpha$, IL-1 $\beta$, and IL-6), of which have demonstrated and emerging role in CHF in recent years [32], no differences where described. This was in line with a previous report [33] where the administration of physiologic concentrations of testosterone to male patients with CHF had no effect on the serum concentrations of TNF- $\alpha$, whether administered acutely over $6 \mathrm{~h}$ or over a longer 12 -week period, either via intramuscular injection or transdermal patch.

Of note, even though this research group previously demonstrated that testosterone therapy was able to reduce QT interval duration in men with CHF [34], with these data confirmed by an independent group a few years later [35], further confirmation of these results was not possible in this larger cohort. Finally, testosterone treatment was well tolerated even though some local reactions caused by the patch preparation were described.

Considering that elderly patients display a deterioration of skeletal muscle strength, affecting early fatigue and limiting exercise tolerance [36,37], in a double-blind, randomized, placebo-controlled study focused on these patients, Caminiti et al. [38] demonstrated that testosterone therapy (12 weeks with very long acting intramuscular $1000 \mathrm{mg}$ testosterone undecanoate) improves functional exercise capacity and muscle strength. In 70 elderly patients with stable CHF and median age of $70 \mathrm{yr}$, peak $\mathrm{VO}_{2}$ and index of muscular strength (e.g., quadriceps maximal voluntary contraction and peak torque) improved in the testosterone group but not in the placebo group. Furthermore, glucose metabolism (HOMA-IR) and baroreflex sensitivity also improved in the testosterone group.

In 2014, Miramadi et al. [39] performed a double-blind, placebo-controlled trial, in which 25 male patients received an intramuscular (gluteal) long-acting androgen injection ( $1 \mathrm{~mL}$ of testosterone enanthate $250 \mathrm{mg} / \mathrm{mL}$ ) once every 4 weeks for 12 weeks. When compared with the placebo arm, the treatment group displayed a significant increasing trend in 6-minute walking distance and quality of life.

Further, Stout et al. [40] demonstrated that testosterone supplementation added to a program of exercise rehabilitation was feasible and can positively impact on a range of key health outcomes in elderly male patients with CHF who have a low testosterone status. Indeed, testosterone treatment (an intramuscular (gluteal) injection of $100 \mathrm{mg}$ testosterone once a fortnight for 12 weeks) induced positive changes in aerobic fitness, leg strength, depression, and androgen deficiency symptoms that were not observed in the placebo group. In this context, a very interesting study was performed by dos Santos and colleagues [41]. In this study, 39 male patients with advanced CHF (NYHA class III) and testosterone deficiency were randomized to training (4-month cycloergometer training), testosterone (intramuscular injection of testosterone undecylate for 4 months), and training + testosterone. Authors not only confirmed that testosterone therapy was able to potentiate the beneficial effects of exercise training in patients with $\mathrm{CHF}$, but provided 
interesting information about the effects of the combined therapies on total body composition, functional capacity, hormonal status, and quality of life, supporting the concept that the peripheral effect of testosterone facilitates the improvement in cardiovascular performance.

Considering the important topic of sex differences in disease [42-47], the effect of testosterone treatment has been investigated also in female populations. In 36 female patients treated with testosterone (300 $\mathrm{mg}$, transdermal patch, twice per week), an improvement in 6-minute walking distance and peak oxygen consumption was observed. In this group, a positive effect was further observed on metabolic pattern (via insulin resistance) [48]. In addition, also in female patients, a direct effect of testosterone to shorten ventricular repolarization in vivo was demonstrated [35].

\section{Clinical implication}

Recently, a meta-analysis performed by Toma and collegues [49] demonstrated that testosterone supplementation in patients with $\mathrm{CHF}$ is associated with a clinically significant improvement in the exercise capacity, expressed as 6-minute walk test distance. Of note, this improvement was greater than that seen with other $\mathrm{CHF}$ treatment (e.g., beta-blockers and ACE inhibitors, etc.). Also $\mathrm{VO}_{2}$ peak and NYHA class improved in patients receiving testosterone treatment.

Because this progress is not associated with an improvement in cardiac structure or function, the cause of these findings is most likely due to peripheral mechanisms, as showed by dos Santos et al. [41].
It is important to underline that only small trial data are available from current literature, recruiting patients with differing characteristics and using alternative routes and dosage of testosterone. Further, all studies are focused in the setting of CHF with reduced ejection fraction (EF) and no data are available about CHF with mildly reduced or preserved EF. Finally, all these studies, because of the short term of their duration, are focused only on the investigation of changes in clinical parameters and not on strong clinical outcome, such as mortality and/or hospitalization. Of note, none of the trials showed a significant change in prostate specific antigen. In the studies using topical testosterone, skin reactions were described. Thus, there are no real safety concerns reported in any of the trials.

Another intriguing issue to argue is that the basal testosterone status was not used in all the studies as a parameter of inclusion or exclusion. Recently, in the context of HD in CHF [50-54], the idea that not all the patients need hormone therapy, but only patients with a deficit of the axis of interest, has improved the outcome and represents the most promising option in this field [55-58]. Finally, considering the high frequency of multiple HD in CHF, no data are available about combined hormone treatment.

\section{Conclusion}

Taken all together, findings from the most recent literature demonstrate that testosterone treatment in CHF is a promising topic that needs further investigation.

Table 1. Summary of studies on testosterone treatment in chronic heart failure.

\begin{tabular}{|c|c|c|c|c|c|c|c|c|}
\hline $\begin{array}{l}\text { First author } \\
\text { [cit] (year) }\end{array}$ & $\begin{array}{l}\text { Sample } \\
\text { size }\end{array}$ & Sex & $\begin{array}{l}\text { Mean age } \\
\text { (years) }\end{array}$ & $\begin{array}{c}\text { NYHA class } \\
(\text { mean } \pm \text { SEM })\end{array}$ & $\begin{array}{l}\text { Testosterone } \\
\text { deficiency }\end{array}$ & $\begin{array}{c}\text { Testosterone } \\
\text { supplementation }\end{array}$ & $\begin{array}{c}\text { Type } \\
\text { of trial }\end{array}$ & $\begin{array}{c}\text { Trial } \\
\text { duration }\end{array}$ \\
\hline $\begin{array}{l}\text { Pugh PJ [29] } \\
(2003)\end{array}$ & 12 & Male & NR & NR & NR & $\begin{array}{c}60 \text { mg orally day } \\
\text { one and day } 2\end{array}$ & $\begin{array}{l}\mathrm{R}, \mathrm{DB}, \mathrm{PC} \\
\text { cross-over }\end{array}$ & 2 days \\
\hline $\begin{array}{l}\text { Malkin CJ [34] } \\
(2003)\end{array}$ & 20 & Male & 61.5 & $2.5 \pm 0.5$ & NR & $\begin{array}{l}\text { Sustanon } 100 \mathrm{mg} \text { IM } \\
\text { every } 2 \text { weeks }\end{array}$ & $\mathrm{R}, \mathrm{DB}, \mathrm{PC}$ & 12 weeks \\
\hline $\begin{array}{l}\text { Pugh PJ [30] } \\
(2004)\end{array}$ & 20 & Male & 62 & NR & NR & $\begin{array}{l}\text { Sustanon } 100 \mathrm{mg} \text { IM } \\
\text { every } 2 \text { weeks }\end{array}$ & $\mathrm{R}, \mathrm{DB}, \mathrm{PC}$ & 12 weeks \\
\hline $\begin{array}{l}\text { Malkin CJ [31] } \\
(2006)\end{array}$ & 76 & Male & 64 & $2.5 \pm 0.6$ & NR & $\begin{array}{c}\text { Androderm } 5 \mathrm{mg} \\
\text { every } 24 \text { hours }\end{array}$ & $\mathrm{R}, \mathrm{DB}, \mathrm{PC}$ & 12 months \\
\hline $\begin{array}{l}\text { Caminiti G [38] } \\
(2009)\end{array}$ & 70 & Male & 70 & $2.5 \pm 0.5$ & NR & $\begin{array}{l}\text { Long-acting testosterone } \\
\text { undecanoate (Nebido) } \\
\text { IM at } 0,6,12 \text { weeks }\end{array}$ & $\mathrm{R}, \mathrm{DB}, \mathrm{PC}$ & 12 weeks \\
\hline $\begin{array}{l}\text { Iellamo F [48] } \\
(2010)\end{array}$ & 32 & Female & 68.7 & $3 \pm 0$ & NR & $\begin{array}{c}\text { Transdermal } \\
\text { testosterone }\end{array}$ & $\mathrm{R}, \mathrm{DB}, \mathrm{PC}$ & 6 months \\
\hline $\begin{array}{l}\text { Schwartz JB [35] } \\
\text { (2011) }\end{array}$ & 84 & $\begin{array}{l}\text { Male }(69 \%) \\
\text { and } \\
\text { Female }(31 \%)\end{array}$ & 70.4 & NR & NR & $\begin{array}{c}\text { Long-acting testosterone } \\
\text { undecanoate } 1,000 \mathrm{mg} \text { IM } \\
\text { at } 0,6,12 \text { weeks }\end{array}$ & $\mathrm{R}, \mathrm{DB}, \mathrm{PC}$ & 12 weeks \\
\hline $\begin{array}{l}\text { Stout M [40] } \\
(2012)\end{array}$ & 41 & Male & 67.2 & $2.5 \pm 0.5$ & $\begin{array}{l}\text { low } \\
\text { testosterone } \\
\text { status }\end{array}$ & $\begin{array}{l}\text { Sustanon } 100 \text { mg IM } \\
\text { every } 2 \text { weeks }\end{array}$ & $\mathrm{R}, \mathrm{DB}, \mathrm{PC}$ & 12 weeks \\
\hline $\begin{array}{l}\text { Mirdamadi A [39] } \\
\text { (2014) }\end{array}$ & 50 & Male & 60 & $2.4 \pm 0.6$ & NR & $\begin{array}{l}\text { Long-acting testosterone } \\
\text { enanthate } 250 \mathrm{mg} \text { IM } \\
\text { every } 4 \text { weeks }\end{array}$ & $\mathrm{R}, \mathrm{DB}, \mathrm{PC}$ & 12 weeks \\
\hline $\begin{array}{l}\text { Dos Santos MR [41] } \\
\text { (2016) }\end{array}$ & 39 & Male & 51 & 3 & $\begin{array}{l}\text { Testosterone } \\
\text { deficiency }\end{array}$ & $\begin{array}{l}\text { intramuscular injection } \\
\text { of long-acting depot } \\
\text { testosterone undecylate }\end{array}$ & $\mathrm{R}$ & 48 weeks \\
\hline
\end{tabular}

R, randomized; DB, double blind; PC, placebo-controlled; NR, not reported; SEM, standard error of the mean 


\section{References}

1. Braunwald E. Heart failure. JACC 2013;1:1-20.

2. Ahmad T, Fiuzat M, Felker GM, 0'Connor C. Novel biomarkers in chronic heart failure. Nat Rev Cardiol 2012;9:347-59.

3. Braunwald E. Biomarkers in heart failure. $\mathrm{N}$ Engl $\mathrm{J}$ Med 2008;358:2148-59.

4. Sirico D, Salzano A, Celentani D, et al. [Anti remodeling therapy: new strategies and future perspective in post-ischemic heart failure: Part I]. Monaldi Arch Chest Dis 2014;82:187-94. [Article in Italian].

5. Salzano A, Sirico D, Arcopinto M, et al. [Anti remodeling therapy: new strategies and future perspective in post-ischemic heart failure. Part II]. Monaldi Arch Chest Dis 2014;82:195-201. [Article in Italian].

6. Alghamdi F, Chan M. Management of heart failure in the elderly. Curr Opin Cardiol 2017;32:217-23.

7. Arcopinto M, et al. Multiple hormone deficiencies in chronic heart failure. Int J Cardiol 2015;184:421-3.

8. Arcopinto, M. et al. Growth hormone deficiency is associated with worse cardiac function, physical performance, and outcome in chronic heart failure: Insights from the T.O.S.CA. GHD Study. PLoS One 2017;12:e0170058).

9. Salzano A, Cittadini A. Bossone E, et al. Multiple hormone deficiency syndrome: a novel topic in chronic heart failure. Future Sci. 2018;4. doi:10.4155/fsoa-2018-0041.

10. Salzano A. et al. Multiple hormone deficiency syndrome in heart failure with preserved ejection fraction. Int J Cardiol 2016;225:1-3.

11. Marra AM, et al. Growth hormone as biomarker in heart failure. Heart Failure Clin 2018;14:65-74.

12. Jankowska EA, et al. Anabolic deficiency in men with chronic heart failure: prevalence and detrimental impact on survival. Circulation 2006;114:1829-37.

13. Jankowska EA, et al. Circulating estradiol and mortality in men with systolic chronic heart failure. JAMA 2009;301:1892-901.

14. Marra AM, et al. Cardiovascular abnormalities and impaired exercise performance in adolescents with congenital adrenal hyperplasia. J Clin Endocrinol Metab 2015;100:644-52.

15. Salzano A, et al. Klinefelter syndrome, cardiovascular system, and thromboembolic disease: review of literature and clinical perspectives. Eur J Endocrinol 2016;175:R27-40.

16. Salzano A, D’Assante R, Heaney LM, et al. Klinefelter syndrome, insulin resistance, metabolic syndrome, and diabetes: review of literature and clinical perspectives. Endocrine 2018;61:194-20.

17. Salzano A, Rocca A, Arcopinto M, et al. Bowel angiodysplasia and myocardial infarction secondary to an ischaemic imbalance: a case report. Open Med (Wars) 2015;10:543-8.

18. Salzano, A. et al. [The portopulmonary hypertension: an overview from diagnosis to treatment]. Monaldi Arch Chest Dis 2013;80;668. [Article in Italian].

19. Marsh JD, et al. Androgen receptors mediate hypertrophy in cardiac myocytes. Circulation 1998;98:256-61.

20. Perusquia M, Stallone JN. Do androgens play a beneficial role in the regulation of vascular tone? Nongenomic vascular effects of testosterone metabolites. Am J Physiol Heart Circ Physiol 2010;298:H1301-7.

21. Tirabassi G, et al. Androgen receptor GGC repeat might be more involved than CAG repeat in the regulation of the metabolic profile in men. Intern Emerg Med 2016;11:1067-75.

22. Brouillette J, Rivard K, Lizotte E, Fiset C. Sex and strain differences in adult mouse cardiac repolarization: importance of androgens. Cardiovasc Res 2005;65:148-57.
23. Cavasin MA, Tao ZY, Yu AL, Yang XP. Testosterone enhances early cardiac remodeling after myocardial infarction, causing rupture and degrading cardiac function. Am J Physiol Heart Circ Physiol 2006;290:H2043-50.

24. Gupta V, et al. Effects of dihydrotestosterone on differentiation and proliferation of human mesenchymal stem cells and preadipocytes. Mol Cell Endocrinol 2008;296:32-40.

25. Filippi $\mathrm{S}$, et al. Testosterone partially ameliorates metabolic profile and erectile responsiveness to PDE5 inhibitors in an animal model of male metabolic syndrome. J Sex Med 2009;6:3274-88.

26. Kelly DM, et al. Testosterone differentially regulates targets of lipid and glucose metabolism in liver, muscle and adipose tissues of the testicular feminised mouse. Endocrine 2016;54:504-15.

27. Oh JY, Barrett-Connor E, Wedick NM, et al. Endogenous sex hormones and the development of type 2 diabetes in older men and women: the Rancho Bernardo study. Diabetes Care 2002;25:55-60.

28. Brand JS, et al. Testosterone, sex hormone-binding globulin and the metabolic syndrome in men: an individual participant data meta-analysis of observational studies. PloS One 2014;9:e100409.

29. Pugh PJ, Jones TH, Channer KS. Acute haemodynamic effects of testosterone in men with chronic heart failure. Eur Heart $\mathrm{J}$ 2003;24:909-15.

30. Pugh PJ, Jones RD, West JN, et al. Testosterone treatment for men with chronic heart failure. Heart 2004;90:446-7.

31. Malkin CJ, et al. Testosterone therapy in men with moderate severity heart failure: a double-blind randomized placebo controlled trial. Eur Heart J 2006;27:57-64.

32. Marra AM, et al. Detectable interleukin-9 plasma levels are associated with impaired cardiopulmonary functional capacity and all-cause mortality in patients with chronic heart failure. Int J Cardiol 2016;209:114-7.

33. Pugh PJ, et al. Physiologic testosterone therapy has no effect on serum levels of tumour necrosis factor-alpha in men with chronic heart failure. Endocr Res 2005;31:271-83.

34. Malkin CJ, Morris PD, Pugh PJ, et al. Effect of testosterone therapy on QT dispersion in men with heart failure. Am J Cardiol 2003;92:1241-3.

35. Schwartz JB, et al. Effects of testosterone on the Q-T interval in older men and older women with chronic heart failure. Int J Androl 2011;34:e415-21.

36. Dharmarajan K, Rich MW. Epidemiology, pathophysiology, and prognosis of heart failure in older adults. Heart Fail Clin 2017;13:417-26.

37. Panjrath G, Ahmed A. Diagnosis and management of heart failure in older adults. Heart Fail Clin 2017;13:427-44.

38. Caminiti G, et al. Effect of long-acting testosterone treatment on functional exercise capacity, skeletal muscle performance, insulin resistance, and baroreflex sensitivity in elderly patients with chronic heart failure a double-blind, placebo-controlled, randomized study. J Am Coll Cardiol 2009;54:919-27.

39. Mirdamadi A, et al. Beneficial effects of testosterone therapy on functional capacity, cardiovascular parameters, and quality of life in patients with congestive heart failure. BioMed Res Int 2014;2014:392432.

40. Stout M, et al. Testosterone therapy during exercise rehabilitation in male patients with chronic heart failure who have low testosterone status: a double-blind randomized controlled feasibility study. Am Heart J 2012;164:893-901.

41. Dos Santos MR, et al. Effect of exercise training and testosterone replacement on skeletal muscle wasting in patients with heart failure with testosterone deficiency. Mayo Clin Proc 2016;91:575-86. 
42. Marra AM, Biskup E, Raparelli V, IMAGINE working group. The Internal Medicine and Assessment of Gender Differences in Europe (IMAGINE): The new European Federation of Internal Medicine initiative on sex and gender medicine. Eur J Intern Med 2018;51:e30-2.

43. Marra AM, et al. Gender-related differences in pulmonary arterial hypertension targeted drugs administration. Pharmacol Res 2016;114:103-9.

44. Salzano A, Demelo-Rodriguez P, Marra AM, Proietti M. A focused review of gender differences in antithrombotic therapy. Curr Med Chem 2017;24: 2576-88.

45. Salzano A, et al. Bleeding related to non-vitamin $\mathrm{K}$ antagonist oral anticoagulants in emergency department: A "Real-world" snapshot from Southern Italy. On behalf of MIRC-NOAC study group. Eur J Intern Med 2018;48:e21-4.

46. Bossone E, et al. Takotsubo cardiomyopathy: an integrated multiimaging approach. Eur Heart J Cardiovasc Imaging 2014;15:366-77.

47. Marra AM, et al. Biomarkers in pulmonary hypertension. Heart Failure Clin 2018;14:393-402.

48. Iellamo F, et al. Testosterone therapy in women with chronic heart failure: a pilot double-blind, randomized, placebo-controlled study. J Am Coll Cardiol 2010;56:1310-6

49. Toma M, et al. Testosterone supplementation in heart failure: a meta-analysis. Circ Heart Fail 2012;5:315-21.

50. Bossone E, et al. Multiple hormonal and metabolic deficiency syndrome in chronic heart failure: rationale, design, and demographic characteristics of the T.O.S.CA. Registry. Intern Emerg Med 2018;13:661-71.

51. Bossone E, et al.The T.O.S.CA. Project: research, education and care. Monaldi Arch Chest Dis 2011;76:198-203.

52. Arcopinto M, et al. The Tosca Registry: An ongoing, observational, multicenter registry for chronic heart failure. Transl Med UniSa 2016;14:21-7.

53. Fazio $\mathrm{S}$, et al. Effects of growth hormone on exercise capacity and cardiopulmonary performance in patients with chronic heart failure. J Clin Endocrinol Metab 2007;92:4218-23.

54. Cittadini A, et al. Insulin-like growth factor-1 protects from vascular stenosis and accelerates re-endothelialization in a rat model of carotid artery injury. J Thromb Haemost 2009;7:1920-8.

55. Cittadini A, et al. Growth hormone replacement delays the progression of chronic heart failure combined with growth hormone deficiency: an extension of a randomized controlled single-blind study. JACC Heart Fail 2013;1:325-30.

56. Cittadini A, et al. Growth hormone deficiency in patients with chronic heart failure and beneficial effects of its correction. J Clin Endocrinol Metab 2009;94:3329-36.

57. Arcopinto M, Salzano A, Isgaard J, Cittadini A. Hormone replacement therapy in heart failure. Curr Opin Cardiol 2015;30:277-84.

58. Napoli R, Salzano A, Bossone E, Cittadini A. Hormonal therapy in the treatment of chronic heart failure. In: Douglas B. Sawyer (editor) Encyclopedia of cardiovascular research and medicine. Oxfors, Elsevier; 2018; p. 508-16. 